\title{
Using Accounting Metrics As Performance Measures To Assess The Impact Of Information Technology Outsourcing On Manufacturing And Service Firms
}

\author{
Pushpa Agrawal, University of Nebraska at Kearney, USA
}

Steven C. Hall, University of Nebraska at Kearney, USA

\begin{abstract}
This study focuses on the information technology (IT) outsourcing decision and asks whether reported financial statement data can measure short-term financial effects of the IT outsourcing decision and thus add to the literature on the benefits of outsourcing. In this study we used accounting metrics derived from archival financial data to assess the impact of IT outsourcing on firms' performance measures. In the sample of 79 firms from 1986 to 2009, there were 45 firms in the manufacturing sector and 34 firms in the service sector. The comparative study between manufacturing and service sectors will help identify where the higher potential of outsourcing impact lies. Firms' performance is measured over a two-year period, one year before and one year after outsourcing decisions were made. For performance measures, we used cost efficiency, productivity, profitability, growth, cash management, and market ratio metrics. Using accounting metrics we show that IT outsourcing has a favorable short-term impact on manufacturing firms' cost efficiency, productivity, and cash management. At the same time outsourcing the IT function has little favorable impact on service firms' short-term performance measures.
\end{abstract}

Keywords: Accounting Metrics; Performance Measures; Information Technology Outsourcing

\section{INTRODUCTION}

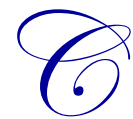

an the use of accounting metrics contribute to our understanding of the short-term effects of Information Technology (IT) outsourcing? IT outsourcing is the contracting out of part or all of a company's IT functions to a third party organization. There has been much research done on the benefits of outsourcing in general and of IT outsourcing in particular. The bulk of this research examines managers' perceptions of benefits derived. We add to this research by examining the effect of IT outsourcing on accounting measures of performance.

Since 1989, when Kodak announced its IT outsourcing contract with three companies for \$250 million over 10 years, organizations in various sectors have begun outsourcing their IT activities (Hall et al., 2005). Worldwide, spending on IT outsourcing was $\$ 821$ billion in 2010 , and will continue to grow further (Gartner Dataquest, 2010). Technological advances, economic and competitive pressures to reduce costs and improve productivity, and institutional developments favoring trade liberalization are the driving factors for IT outsourcing (Olsen, 2006; Kotabe et al., 2009).

Outsourcing firms derive benefits from vendors' specialization and scale, learning that improves process performance with better IT systems, increased managerial flexibility, and the ability to focus on core competencies (Clemons et al., 2000; DiRonualdo \& Gurbaxani, 1998; Levina \& Ross, 2003; Thouin et al., 2009). Corporate executives who favor outsourcing their IT infrastructure believe that it leads to reduced operating expenses, increased flexibility, improved management focus, improved quality of service, and access to state-of-the-art technology (Barthelemy, 2001; Kishore et al., 2003). 
Researchers of IT outsourcing rely primarily on managers' estimates of performance benefits, and it is not clear how well the estimates correlate to actual performance (Jiang et al., 2007). Managers' estimates, while useful, may be skewed by the cognitive biases which sometimes lead to perceptual distortion, inaccurate judgment, illogical interpretation, or what is broadly called irrationality (Ramchandran \& Gopal, 2010).

Aubuchon et al. (2012) reviewed sixteen studies on the impact of outsourcing on employment and firm performance in manufacturing and service industries. They found that more studies are in manufacturing sectors than in service sectors and that none of them used archival financial data and focused on IT outsourcing.

In this study, we examined the impact of firms' IT outsourcing on their performance measures (cost efficiency, productivity, profitability, growth, cash management, and market ratio) using audited financial data in manufacturing and service industries.

\section{HYPOTHESES DEVELOPMENT}

Smith et al. (1998) used a set of six performance metrics to study a firm's pre-outsourcing characteristics, grouped into the categories: cost efficiency, productivity, growth, cash management, profitability, and market ratio. We use these six performance metrics to examine the effect of IT outsourcing on firms' post-outsourcing performance.

\section{Cost Efficiency}

Bardhan et al. (2006) stated that a survey of 318 global companies active in outsourcing revealed that 61 percent found cost saving, 57 percent reported increased ability to focus on core business, and 50 percent experienced improvements in process speed, quality, and accuracy. The vendor can provide the same level of service at a lower cost than the outsourcing firm through economy of scale, lower labor costs, and focused expertise (Roodhooft \& Warlop, 1999). Lacity et al. (1996) and Saunders et al. (1997) found a cost savings of up to forty percent in their case study.

H1: Accounting measures of cost efficiency will improve for firms that enter into outsourcing contracts relative to firms that do not enter into such contracts.

We use selling and administration expenses ( $\mathrm{SG \& A}$ ) expressed as a percentage of sales as the cost efficiency measure.

\section{Productivity}

Vendors are more efficient than outsourcing firms and provide better systems, thus improving clients' performance and productivity (Amiti \& Wei, 2006; Gorg et al., 2008). In addition, Chang and Gurbaxani (2012) find that firms achieve productivity gains of up to six percent from IT outsourcing. Amiti and Wei (2009) find that manufacturing firms achieve productivity gains of around ten percent by outsourcing their service activities. Mann (2003) stated that offshoring in the US IT industry increased productivity by 0.3 percent per year for the period 1995 to 2002 , which translates into a cumulative effect of $\$ 230$ billion in additional GDP.

H2: Accounting measures of productivity will increase for firms that enter into IT outsourcing contracts relative to firms that do not enter into such contracts. equipment.

We used two productivity measures; i.e., sales/average assets and sales/average property, plant, and

\section{Profitability}

While the greatest effect on profitability will be the long-term effect of the company focusing on the core business, some short-term profitability effect should also be evident. There may be decreased costs from offshoring to developing countries and decreased investment in IT assets. 
H3: Accounting measures of profitability will increase for firms that enter into IT outsourcing contracts relative to those that do not enter into such contracts.

We use three profitability measures, each with income before taxes, depreciation, and extraordinary items (IBE) in the numerator; i.e., return on assets (IBE/average assets); return on equity (IBE/average common stockholder's equity); and net profit margin (IBE/sales).

\section{Growth}

IT outsourcing firms may provide more timely and cost-effective delivery and higher-quality service to customers than non-outsourcing firms because vendors have state-of-the-art technologies and enhanced IT competence and experience. Outsourcing firms are able to offer customized and differentiated products and services to customers, and this should be reflected in increased sales (Wang et al., 2008).

H4: Accounting measures of growth will increase for firms that enter into IT outsourcing contracts relative to firms that do not enter into such contracts.

In this study we evaluate current growth as change in sales measured as (Sales(t) - Sale(t-1))/Sale(t-1).

\section{Cash Management}

Outsourcing firms receive cash from vendors for their tangible and intangible assets and use the cash to repay their debts. Cash management metrics signify the degree of the firm's liquidity and its use of debt financing.

H5: Debt ratios will decrease for firms that enter into IT outsourcing contracts relative to firms that do not enter into such contracts.

To measure liquidity we use total liabilities/sales, long-term debt/sales, current liabilities/sales, and financial leverage (total liabilities/common stockholder's equity).

\section{Market Ratio}

Outsourcing firms may generate more cash and have higher profitability, enabling them to pay more dividends to their stockholders. Market ratio relates the market value of shareholders' equity and the dividends paid to them. As a measure, we used dividends paid to shareholders divided by sales.

H6: The dividend/sales ratio will increase for firms that enter into IT outsourcing contracts relative to firms that do not enter into such contracts.

\section{RESEARCH METHODOLOGY}

\section{Sample and Data Source}

We used the Factiva database to identify IT outsourcing announcements using two media: the Wall Street Journal and Dow Jones Publications. We included firms publicly announcing an IT outsourcing contract from January 1, 1986 to September 30, 2009. We used keywords "outsourcing OR offshoring" AND "announcement OR contract OR deals" to search for IT outsource announcements. We selected IT outsourcing announcements of \$5 million or more, and our sample represents contract lengths from 1 year to 15 years. Pouder at al. (2011) noted that other factors also can influence firms' performance while they are outsourcing their IT activities. We therefore eliminated the firms that announced a strike, acquisition, merger, etc. Our sample has 79 firms (45 manufacturing and 34 service) which had announced contracts to outsource their IT activities.

We used publicly audited financial data from the COMPUSTAT database to examine the short-term effect of IT outsourcing. We used the data to test for changes in firms' performance over a period of four quarters prior to 
and four quarters after the announcement. We also compared the performance between the outsourcing firms (treatment group) and closely matched non-outsourcing firms (control group).

\section{Control Group}

We compared the outsourcing firms' performance with non-outsourcing firms. We created a control group, choosing a firm that most closely matched each treatment firm in terms of size and industry. We did matched pair analysis to compare the performance between the treatment and control group.

We matched treatment and control firms by SIC code and book value of total assets under the assumption that firms of similar size in the same industry are subject to similar economic and competitive factors (Hendricks \& Singhal, 1997). Sixty-nine firms were matched by 4-digit SIC code, three firms by 3-digit code, six firms by 2-digit codes, and one firm by 1-digit code. Book values of control firms ranged from 50 to 300 percent of the treatment firms' book values.

We labeled the IT outsourcing announcement quarter as Quarter (Q) 0. The four quarters before the announcement are Quarter -1, Quarter -2, Quarter -3, and Quarter -4 respectively: while the four quarters after the announcement are Quarter 1, Quarter 2, Quarter 3, and Quarter 4 respectively. We calculated the changes in performance over the quarter intervals as in Jiang and Qureshi (2006) for manufacturing and service firms as follows:

1. For changes before the IT outsourcing announcements,

Change in performance= Metric @Q(i+1) - Metric@Q(i)

We calculated the change in performance from Quarter -4 to Quarter -3, Quarter -3 to Quarter -2, Quarter 2 to Quarter -1, and Quarter -1 to Quarter 0.

2. For changes after outsourcing announcements

Change in performance= Metric@Q(i) - Metric@Q $(0)$

We calculated the change in performance from Quarter 0 to Quarter 1, Quarter 0 to Quarter 2, Quarter 0 to Quarter 3, and Quarter 0 to Quarter 4.

\section{RESULTS}

\section{Pre-Event Performance Result}

We first calculated the pre-event performance between the treatment group and the control group for different metrics and compared them using two-tailed paired t-tests. We calculated changes in performance from quarter to quarter, for example, from Q-4 to Q-3, Q-3 to Q-2 and so on. Results are reported in Table 1.

For the manufacturing sector, the significant differences in PPE turnover (Q-4), return on equity (Q-4), growth (Q-4), total liabilities/sales (Q-4), and current liabilities/sales (Q-4) are favorable to the control group, while SG\&A/sales (Q-1), net profit margin (Q-1), current liabilities/sales (Q-3), and dividend/sales (Q-4) are favorable to the treatment group. These results show that there are no significant differences in 39 out of 48 comparisons; thus, before the IT outsourcing announcements, the performance of treatment group firms was roughly the same as that of their matching control firms (Table 1, manufacturing sector).

In the service sector, the significant differences in $\mathrm{SG \& A} /$ sales $(\mathrm{Q}-1)$, asset turnover (Q-1), net profit margin (Q-3), total liabilities/sales (Q-1), and current liabilities/sales (Q-1) are favorable to the treatment group, while SG\&A/sales (Q-2 and Q-4), net profit margin (Q-4), financial leverage (Q-4 and Q-2), and dividend/sales (Q1 and Q-3) are favorable to the control group. It appears that the control group firms' performance was slightly 
better than the treatment group, and at the same time there are no significant differences for 36 out of 48 comparisons (Table 1, service sector).

Table 1: Pre-Event Quarterly Performance

\begin{tabular}{|c|c|c|c|c|c|c|c|c|c|}
\hline \multicolumn{10}{|c|}{ Pre-Event Quarterly Performance Between Treatment and Control Groups } \\
\hline \multirow{2}{*}{ Metrics } & \multirow{2}{*}{$\begin{array}{c}\text { Favorable } \\
\text { Change }\end{array}$} & \multicolumn{4}{|c|}{ Manufacturing } & \multicolumn{4}{|c|}{$\begin{array}{ll}\text { Service } \\
\end{array}$} \\
\hline & & Q -1 & Q -2 & $Q-2$ & Q -1 & Q -1 & Q -2 & Q -2 & Q -1 \\
\hline SG\&A/Sales & - & 0.0085 & 0.0306 & 0.0060 & $-0.0167 *$ & $0.0253 * *$ & 0.0558 & $0.0485 *$ & $-0.0488 *$ \\
\hline Asset Turnover & + & -0.0102 & -0.0006 & -0.0006 & -0.0048 & -0.0276 & -0.0005 & 0.0037 & $0.0361 * *$ \\
\hline PPE Turnover & + & $-0.1275^{* *}$ & 0.0285 & 0.0072 & 150 & -0.2621 & 0.1708 & 0.0719 & 0.1231 \\
\hline Return on Assets & + & -0.0016 & -0.0005 & 0.0032 & 0.0034 & -0.0059 & 0.0021 & 0.0001 & 0.0059 \\
\hline Return on Equity & + & $-0.1680 *$ & 0.3023 & -0.2676 & -0.2963 & 0.0063 & -0.1349 & -0.3350 & 0.0911 \\
\hline Net Profit Margin & + & -0.0015 & -0.0003 & 0.0133 & $0.0223 *$ & $-0.0308 *$ & $0.0515 *$ & -0.0214 & 0.0259 \\
\hline Growth (sales) & + & $-0.1242 * *$ & 0.0668 & -0.0164 & -0.0049 & -0.0850 & -0.0043 & 0.0711 & 0.0593 \\
\hline Total Liabilities/ Sales & - & $0.2687 *$ & 0.0804 & -0.0708 & 0.1195 & 0.2347 & 0.2144 & 0.1066 & $-0.6825^{*}$ \\
\hline Long-term Debt/Sales & - & -0.0029 & 0.1742 & -0.1071 & 0.0241 & 0.0132 & 0.2564 & -0.3486 & -0.0954 \\
\hline Current Liabilities/Sales & - & $0.1560 * *$ & $-0.1145 *$ & -0.0420 & 0.1724 & 0.1395 & -0.0346 & -0.0264 & $-0.3187 * *$ \\
\hline Financial Leverage & - & 0.3223 & 0.1359 & -0.0651 & -0.7854 & $0.5359 * *$ & -0.0720 & $0.2315^{*}$ & 0.0537 \\
\hline Dividend/Sales & + & $0.0032 * *$ & -0.0008 & 0.0034 & -0.0027 & 0.0020 & $-0.0057 *$ & 0.0002 & $-0.0022 * *$ \\
\hline
\end{tabular}

Note: two tailed paired t-test, * 10 percent level, $* * 5$ percent level, and $* * * 1$ percent level

\section{Post-Event Performance Result}

We use one sample t-statistic (one-tail) for mean values of treatment firms' performance metrics, and change within the treatment group to identify the significant change rate. We also use a one-tailed paired-sample ttest to test the comparative performance between treatment and control groups to identify the significant change rate. Results are reported in Tables 2 and 3.

Table 2: Quarterly Comparisons and Trends - Manufacturing

Post-Event Quarterly Change in Performance Within Group and in Comparison to the Control Group - Manufacturing

\begin{tabular}{|c|c|c|c|c|c|c|c|c|c|}
\hline \multirow[t]{3}{*}{ Metrics } & \multirow[t]{3}{*}{$\begin{array}{l}\text { Favorable } \\
\quad \text { Sign }\end{array}$} & \multicolumn{4}{|c|}{$\begin{array}{c}\text { Mean Change Rate Within Treatment } \\
\text { Group }\end{array}$} & \multirow{2}{*}{\multicolumn{4}{|c|}{$\begin{array}{c}\text { Comparative Performance Between } \\
\text { Treatment and Control Groups } \\
\text { (Treatment - Control) }\end{array}$}} \\
\hline & & \multicolumn{4}{|c|}{ Individual-Quarter Effects } & & & & \\
\hline & & Q 1 & Q 2 & Q 3 & Q 4 & Q 1 & Q 2 & Q 3 & Q 4 \\
\hline Cost Efficiency: & & & & & & & & & \\
\hline $\begin{array}{l}\text { SG\&A/Sales } \\
\text { Productivity: }\end{array}$ & - & $0.0117 *$ & -0.0043 & -0.0115 & $-0.0118 *$ & 0.0136 & 0.0042 & $-0.0421 *$ & -0.0181 \\
\hline Asset Turnover & + & -0.0002 & 0.0071 & 0.0088 & $0.0106 *$ & 0.0039 & $0.0143 *$ & 0.0130 & 0.0067 \\
\hline $\begin{array}{l}\text { PPE Turnover } \\
\text { Profitability: }\end{array}$ & + & 0.0079 & 0.0870 & 0.1068 & $0.1173 *$ & 0.0083 & 0.1043 & 0.1092 & $0.1784 * *$ \\
\hline Return on Assets & + & 0.0003 & 0.0024 & $0.0047 *$ & 0.0023 & -0.0027 & 0.0021 & 0.0030 & -0.0046 \\
\hline Return on Equity & + & -0.7919 & $0.2077 *$ & $0.1792 *$ & -0.0140 & -0.8987 & 0.1761 & 0.0983 & $-0.1239 * *$ \\
\hline $\begin{array}{l}\text { Net Profit Margin } \\
\text { Growth: }\end{array}$ & + & 0.0051 & 0.0108 & $0.0162 *$ & 0.0119 & $-0.0189 *$ & 0.0137 & 0.0097 & 0.0167 \\
\hline $\begin{array}{l}\text { Sales Growth } \\
\text { Cash Management: }\end{array}$ & + & 0.0550 & $0.0503 *$ & 0.0065 & 0.0009 & 0.0762 & 0.0680 & -0.1481 & 0.0116 \\
\hline Total Liabilities/Sales & - & -0.1820 & -0.2709 & -0.2333 & -0.2929 & -0.1773 & $-0.7212 * *$ & -0.4683 & -0.4209 \\
\hline Long-term Debt/Sales & - & 0.1710 & -0.0108 & -0.0025 & -0.0900 & $-0.2290 *$ & $-0.3379 *$ & -0.0900 & -0.1176 \\
\hline Current Liabilities/Sales & - & -0.1218 & -0.2153 & $-0.2816^{*}$ & -0.2490 & -0.2305 & -0.2594 & -0.2889 & -0.3056 \\
\hline $\begin{array}{l}\text { Financial Leverage } \\
\text { Market Ratio: }\end{array}$ & - & -0.0557 & -0.1195 & -0.0832 & -0.1056 & 0.3283 & -0.3702 & 0.1642 & 0.2766 \\
\hline Dividends/Sales & + & 0.0001 & $-0.0028 *$ & -0.0024 & -0.0013 & -0.0019 & $-0.0048 *$ & -0.0026 & -0.0032 \\
\hline
\end{tabular}

Notes: one tail t-test, $* 10$ percent level, $* * 5$ percent level, and $* * * 1$ percent level

\section{Cost Efficiency}

The outsourcing firms in the manufacturing sector show significant cost savings by Q4 and significant advantage over non-outsourcing firms by Q3. For the service sector, the analysis shows that outsourcing events have 
significant negative impact on outsourcing firms' cost efficiency metrics, both within the treatment group and in comparison with control group.

\section{Productivity}

For the manufacturing sector, the archival data analysis reveals that the mean change rate of asset turnover and PPE turnover in the treatment group were significantly favorable, as were the metrics in comparison to the control group. In the service sector, results are significantly unfavorable to outsourcing firms.

\section{Profitability}

In the manufacturing sector, outsourcing firms appear to increased profitability but not in comparison to control firms. In the service sector, outsourcing firms appear to have declined in profitability both within the group and between groups.

Growth

The archival data analysis for the manufacturing sector supports the growth metric within the group but not between groups. In the service sector growth is significantly negative both within the group and between groups.

Table 3: Quarterly Comparisons and Trends - Service

Post-Event Quarterly Change in Performance Within Group and in Comparison to the Control Group - Manufacturing

\begin{tabular}{|c|c|c|c|c|c|c|c|c|c|}
\hline \multirow[t]{3}{*}{ Metrics } & \multirow[t]{3}{*}{$\begin{array}{l}\text { Favorable } \\
\text { Sign }\end{array}$} & \multirow{2}{*}{\multicolumn{4}{|c|}{$\begin{array}{l}\begin{array}{c}\text { Mean Change Rate Within Treatment } \\
\text { Group }\end{array} \\
\text { Individual-Ouarter Effects }\end{array}$}} & \multirow{2}{*}{\multicolumn{4}{|c|}{$\begin{array}{c}\text { Comparative Performance Between } \\
\text { Treatment and Control Groups } \\
\text { (Treatment - Control) } \\
\text { Individual-Quarter Effects }\end{array}$}} \\
\hline & & & & & & & & & \\
\hline & & Q 1 & Q 2 & Q3 & Q4 & Q 1 & Q 2 & Q 3 & Q 4 \\
\hline $\begin{array}{l}\text { Cost Efficiency: } \\
\text { SG\&A/Sales } \\
\text { Productivity: }\end{array}$ & - & 0.0135 & -0.0074 & $0.0191 *$ & 0.0051 & $0.0458 * *$ & $0.0275^{*}$ & $0.0435^{* *}$ & 0.0179 \\
\hline Asset Turnover & + & $-0.0225 * *$ & -0.0094 & $-0.0414 * *$ & $-0.0275^{*}$ & $-0.0475 * * *$ & $-0.0346^{*}$ & $-0.0716^{* *}$ & $-0.0374 *$ \\
\hline $\begin{array}{l}\text { PPE Turnover } \\
\text { Profitability: }\end{array}$ & + & $-0.3208 *$ & -0.1049 & -0.8165 & -0.6082 & $-0.5101 * *$ & -0.2501 & $-1.4372 *$ & -1.0241 \\
\hline Return on Assets & + & $-0.0041 * *$ & 0.0035 & $-0.0047 * *$ & -0.0017 & $-0.0109 *$ & -0.0045 & $-0.0103 *$ & -0.0020 \\
\hline Return on Equity & + & $-0.3418 * *$ & -0.5239 & -0.2969 & 0.0961 & $-0.4196 * *$ & -0.5965 & $-0.3593 *$ & 0.0476 \\
\hline $\begin{array}{l}\text { Net Profit Margin } \\
\text { Growth: }\end{array}$ & + & 0.0015 & $0.0207 * *$ & $-0.0307 *$ & -0.0373 & -0.0423 & -0.0193 & -0.0370 & -0.0176 \\
\hline $\begin{array}{l}\text { Sales Growth } \\
\text { Cash Management: }\end{array}$ & + & $-0.0939 * *$ & 0.0227 & $-0.0857 * * *$ & -0.0200 & $-0.3025 * *$ & -0.0486 & $-0.1184 * *$ & -0.0364 \\
\hline Total Liabilities/Sales & - & $0.7718 * *$ & 0.3747 & 0.1154 & $0.6877 * *$ & $1.3008 * * *$ & -0.0446 & -0.1567 & 0.3891 \\
\hline Long-term Debt/Sales & - & $0.2711^{*}$ & 0.2514 & 0.1899 & $0.3725^{*}$ & 0.2437 & 0.2084 & 0.1021 & 0.1634 \\
\hline $\begin{array}{l}\text { Current } \\
\text { Liabilities/Sales }\end{array}$ & - & $0.1368 * * *$ & -0.0060 & 0.0655 & -0.0274 & $0.2129 * *$ & 0.1503 & $0.2701 * *$ & $0.2863 *$ \\
\hline $\begin{array}{l}\text { Financial Leverage } \\
\text { Market Ratio: }\end{array}$ & - & 0.0343 & 0.1547 & -2.4834 & -0.0146 & 0.0426 & 0.1316 & -2.5323 & 0.5041 \\
\hline Dividends/Sales & + & $0.0021 *$ & 0.0006 & 0.0013 & 0.0018 & 0.0036 & 0.0012 & 0.0037 & 0.0029 \\
\hline
\end{tabular}

Notes: one tail t-test, $* 10$ percent level, $* * 5$ percent level, and $* * * 1$ percent level

\section{Cash Management}

Results for cash management metrics are mostly all in the direction predicted for the manufacturing firms. There is a significant favorable result for current liabilities/sales within group and for total liabilities/sales and longterm debt/sales between groups. The archival data analysis of service firms reveals that outsourcing events have significant negative impact on outsourcing firms' cash management metrics, both within the treatment group and in comparison with the control group. 
Market Ratio

The manufacturing sector results are significantly unfavorable, both within the group and between the groups for outsourcing firms' market ratio metrics. Our data analysis of the service sector shows outsourcing firms have significant advantage in market ratio metrics within the treatment group.

\section{DISCUSSION AND CONCLUSION}

The purpose of this study is to examine the effect of IT outsourcing on firms' accounting based performance metrics. The study helps firms in making a rational decision about outsourcing their IT activities and demonstrates the contribution to the research of using accounting metrics to measure outcomes of the IT outsourcing decision.

This paper has examined the relationship between IT outsourcing and manufacturing and service firms' performance using the audited archival financial data from January 1, 1986 to September 30, 2009. The performance of outsourcing and non-outsourcing firms is similar in four quarters prior to when firms outsourced their IT activity. The performance of outsourcing and not outsourcing firms differed significantly in the four quarters subsequent to the outsourcing event.

In the manufacturing sector it appears that outsourcing firms, in a very short time frame, are more efficient in costs and in liabilities and more productive in the use of resources. On the other hand, in the services sector, outsourcing firms are less efficient in costs and in liabilities, less productive, and less profitable. We have no good explanation for the difference in performance between manufacturing firms and service firms but believe the finding is significant. The effects of outsourcing differ in important ways between service and manufacturing firms. This may be a fruitful area for future investigation.

While we provide an integrative framework to analyze the impact of IT outsourcing on firms' performance, our study is not without limitations. Our analysis was limited by what is available in public databases and was also limited mostly to larger firms. In the COMPUSTAT database, separate data for IT departments are not available. The data on outsourcing arrangements are collected from press releases, which may favor larger IT outsourcing deals, as these often get more attention from the news media. Therefore we need to be cautious in generalizing our results to smaller firms.

The sample size of 45 manufacturing firms and 34 service firms is relatively small. To get precise results we need larger sets of data. We have analyzed the short-term effect of IT outsourcing, but at times the effect of outsourcing appears in the long-term; therefore, further study should include long-term effects of outsourcing. Different types of contracts, such as domestic vs. offshoring, or long-term vs. short-term, may perform differently. Therefore different types of contracts should be analyzed separately.

\section{DATA AVAILABILITY}

All data are available from public sources.

\section{AUTHOR INFORMATION}

Pushpa Agrawal is adjunct faculty of accounting at the University of Nebraska at Kearney. She completed her MBA in Accounting from University of Nebraska at Kearney in 2008 and Ph.D. from Singhania University, India in 2012. Her research has been published/accepted in International Journal of Management \& Information Systems, International Journal of Management, and Economics \& Business Journal: Inquiries \& Perspective, and has presented at conferences such as National Decision Sciences Institute and Mountain Plains Management conference. Pushpa Agrawal, Adjunct Accounting Faculty, University of Nebraska at Kearney, USA. E-mail: agrawalp1@unk.edu 
Steven C. Hall is professor of accounting at the University of Nebraska at Kearney. He became a CPA in 1984 and received his Ph.D. in business administration (major area-accounting) from the University of Utah in 1990. He teaches financial accounting and auditing. His research interests include the usefulness of accounting numbers and earnings management and his research has appeared in The Accounting Review, Journal of Accounting and Public Policy, Journal of Business Finance and Accounting, Journal of Accounting Education, Accounting Educators' Journal, Journal of Theoretical Accounting Research, and other academic journals. Steven C. Hall, Professor of Accounting, University of Nebraska at Kearney, USA. E-mail: hallsc@ unk.edu (Corresponding author)

\section{REFERENCES}

1. Amiti, M., \& Wei, S. J. (2006). Service offshoring and productivity: Evidence from the United States. (NBER Working Paper No. 11926). Cambridge, MA: National Bureau of Economic Research.

2. - ----- 2009. Service offshoring and productivity: Evidence from the US. The World Economy, 203-220.

3. Aubuchon, C., Bandyopadhyay, S., \& Bhaumik, S. K. (2012). The extent and impact of outsourcing: Evidence from Germany. Federal Reserve Bank of St. Louis Review, July/August, 287-305.

4. Bardhan, I., Whitaker, J., \& Mithas, S. (2006). Information technology, production process outsourcing, and manufacturing plant performance. Journal of Management Information Systems, 25(2), 13-40.

5. Barthelemy, J. (2001). The hidden cost of IT outsourcing. Sloan Management Review, 42(3), 60-69.

6. Chang, Y. B., \& Gurbaxani, V. (2012). Information technology outsourcing, knowledge transfer, and firm productivity: An empirical analysis. MIS Quarterly, 36(4), 1043-1063.

7. Clemons, E., Hitt, L., \& Snir, E. (2000). A risk analysis framework for IT outsourcing. (Working Paper). The Wharton School, University of Pennsylvania.

8. DiRomualdo, A., \& Gurbaxani, V. (1998). Strategic intent of IT outsourcing. Sloan Management Review, 39(4), 67-80.

9. Gartner Dataquest (2010). Gartner says worldwide IT spending to grow 5.3 percent in 2010. Retrieved from www.gartner.com

10. Gorg, H., Hanley, A., \& Strobl, E. (2008). Productivity effects of international outsourcing: Evidence from plant-level data. Canadian Journal of Economics, 41(2), 670-688.

11. Hall, J. A., \& Liedtka, S. L. (2005). Financial performance, CEO compensation, and large-scale information technology outsourcing decisions. Journal of Management Information Systems, 22(1), 193221.

12. Hendricks, K. B., \& Singhal, V. R. (1997). Does implementing an effective TQM program actually improve operating performance? Empirical evidence from firms that have won quality awards. Management Science, 43(9), 1258-1274.

13. Jiang, B., Belohlav, J. A., \& Young, S. T. (2007). Outsourcing impact on manufacturing firms' value: Evidence from Japan. Journal of Operations Management, 25, 885-900.

14. Jiang, B., \& Qureshi, A. (2006). Research on outsourcing results: Current literature and future opportunities. Management Decision, 44(1), 44-55.

15. Kishore, R. M., Rao, H. R., Nam, K., Rajgopalan, S., \& Chaudhury, A. (2003). A relationship perspective on IT outsourcing. Communications of the ACM, 46(12), 86-92.

16. Kotabe, M., \& Mol, M. J. (2009). Outsourcing and financial performance: A negative curvilinear effect. Journal of Purchasing \& Supply Management, 15, 205-213.

17. Lacity, M. C., Willcocks, L., \& Feeny, D. (1996). The value of selective IT sourcing. Sloan Management Review, 37(3), 13-25.

18. Levina, N., \& Ross, J. (2003). From the vendor's perspective: Exploring the value proposition in information technology outsourcing. MIS Quarterly, 27(3), 331-364.

19. Mann, C. (2003). Globalization of IT services and white collar jobs: The next wave of productivity growth. International Economics Policy Brief. No. PB03-1. Washington, DC: Peterson Institute for International Economics.

20. Olsen, K. B. (2006). Productivity impacts of offshoring and outsourcing: A review. Organization for Economic Co-operation and Development. (STI Working Paper 2006/1).

21. Pouder, R. W., Cantrell, R. S., \& Daly, J. P. (2011). The impact of outsourcing on firm value: New insights. SAM Advanced Management Journal, Spring, 4-13. 
22. Ramchandran, V., \& Gopal, A. (2010). Managers' judgments of performance in IT services outsourcing. Journal of Management Information Systems, 26(4), 181-218.

23. Roodhooft, F., \& Warlop, L. (1999). On the role of sunk costs and asset specificity in outsourcing decisions: A research note. Accounting, Organization, and Society, 24, 363-369.

24. Saunders, C., Gebelt, M., \& Hu, Q. (1997). Achieving success in information systems outsourcing. California Management Review, 39(2), 63-79.

25. Smith, M. A., Mitra, S., \& Narasimhan, S. (1998). Information systems outsourcing: A study of pre-event firm characteristics. Journal of Management Information Systems, 15(2), 61-93.

26. Thouin, M. F., Hoffman, J. J., \& Ford, E. W. (2009). IT outsourcing and firm-level performance: A transaction cost perspective. Information \& Management, 46, 463-469.

27. Wang, L., Gwebu, K. L., Wang, J., \& Zhu, D. X. (2008). The aftermath of information technology: An empirical study of firm performance following outsourcing decisions. Journal of Information Systems, 22(1), 125-159. 


\section{$\underline{\text { NOTES }}$}

